\title{
DNA-based identification of forensically important species of Sarcophagidae (Insecta: Diptera) from Rio de Janeiro, Brazil
}

K.S. Napoleão ${ }^{1,4}$, C.A. Mello-Patiu ${ }^{2}$, J. Oliveira-Costa ${ }^{3}$, D.M. Takiya ${ }^{4}$, R. Silva ${ }^{5}$ and R.S. Moura-Neto ${ }^{1,4}$

${ }^{1}$ DIMAV, Instituto Nacional de Metrologia, Qualidade e Tecnologia, Duque de Caxias, RJ, Brasil

${ }^{2}$ Departamento de Entomologia, Museu Nacional, Universidade Federal do Rio de Janeiro, Rio de Janeiro, RJ, Brasil

${ }^{3}$ Laboratório de Entomologia Forense, Instituto de Criminalística Carlos Éboli, Departamento Geral de Polícia Técnico Científica, Polícia Civil do Estado do Rio de Janeiro, Rio de Janeiro, RJ, Brasil ${ }^{4}$ Instituto de Biologia, Universidade Federal do Rio de Janeiro, Rio de Janeiro, RJ, Brasil ${ }^{5}$ Instituto de Biofísica Carlos Chagas Filho, Universidade Federal do Rio de Janeiro, Rio de Janeiro, RJ, Brasil

Corresponding author: R.S. Moura-Neto

E-mail: rodrigomouraneto@ufrj.br

Genet. Mol. Res. 15 (2): gmr.15027705

Received September 23, 2015

Accepted November 17, 2015

Published May 6, 2016

DOI http://dx.doi.org/10.4238/gmr.15027705

\begin{abstract}
Sarcophagidae, or flesh flies, are of great importance in forensic entomology, but their effective application requires precise taxonomic identification, which relies almost exclusively on characteristics of the male genitalia. Given that female flies and larvae are most abundant in animal carcasses or on corpses, precise morphological identification can be difficult; therefore, DNA sequencing can be an additional tool for use in taxonomic identification. This paper analyzes part of the mitochondrial cytochrome c oxidase subunit I (COI) gene
\end{abstract}


from three Sarcophagidae species of forensic importance in the City of Rio de Janeiro: Oxysarcodexia fluminensis, Peckia chrysostoma, and Peckia intermutans. COI fragments of $400 \mathrm{bp}$ from 36 specimens of these three species were sequenced. No intraspecific differences were found among specimens of $O$. fluminensis, but $P$. chrysostoma and $P$. intermutans each had two haplotypes, ranging from 0 to $0.7 \%$. The interspecific divergence was $8.5-11.6 \%$, corroborating previously reported findings.

Key words: COI gene; Forensic entomology; Sarcophagidae

\section{INTRODUCTION}

Flies represent the most important insect order used for forensic purposes, especially because members of the Calliphoridae, Muscidae, and Sarcophagidae families are the first and most frequent colonizers of corpses (Smith, 1986). Morphological examination is used to identify characteristics of the male genitalia, and there are few taxonomic features that can be easily used by non-specialists for species identification (Carvalho and Mello-Patiu, 2008; Giroux et al., 2010). Furthermore, few tools are available for the identification of forensically important fly species (Giroux et al., 2010) and these are constantly outdated in regions where the diverse insect fauna is understudied. These difficulties limit the use of entomological data by the forensic investigator.

Sarcophagid flies (flesh flies) are potentially useful dipterans for forensic purposes because most of these species have necrophagous larvae. However, their performance has been underestimated because most individuals that are attracted to carcasses are females, which use them to lay larvae (Byrd and Castner, 2011). The identification of females and immature flies is difficult because of their conservative morphology and there are very few or no morphological differences between species.

As compared with Calliphoridae, only a few studies on community succession on carcasses in Brazil have included data on Sarcophagidae (Moura et al., 1997; Carvalho et al., 2000; Carvalho et al., 2004; Barbosa et al., 2009) in Rio de Janeiro (Barbosa et al., 2009). Some species have been suggested as possible indicators for forensic purposes, including: Oxysarcodexia fluminensis (Lopes, 1946), Peckia (Pattonella) intermutans (Walker, 1861), and Peckia (Peckia) chrysostoma (Wiedemann, 1830).

DNA-based techniques have been used as successful alternatives to morphological examination for taxonomic identification of species of forensic interest (Wells et al., 2001; Schroeder et al., 2003; Wells and Stevens, 2008; Saigusa et al., 2009; Meiklejohn et al., 2011; Tan et al., 2010; Guo et al., 2012). Molecular identification is advantageous because it can be applied to any stage of development and to adult flies of any gender. The large number of publicly available sequences of the mitochondrial gene cytochrome c oxidase subunit I (COI) gene has made this marker the most widely used in forensic studies.

Nevertheless, DNA-based identification relies on an extensive database of sequences derived from correctly identified individuals. Therefore, because no molecular data are available on Sarcophagidae from Rio de Janeiro, our goal was to analyze part of the mitochondrial COI 
gene from three Sarcophagidae species of forensic importance in the Rio de Janeiro County in order to initiate the formation of a molecular database for these species.

\section{MATERIAL AND METHODS}

We selected a total of 36 specimens comprising three species that were of potential forensic importance (Carvalho et al., 2000; Barbosa et al., 2009; Barbosa et al., 2010; Oliveira and Vasconcelos, 2010), namely: O. fluminensis, P. intermutans, and P. chrysostoma. To determine possible haplotype variations of the population, these species were sampled at three sites in the City of Rio de Janeiro. Collected material was preserved in $95 \%$ ethanol and maintained at $4{ }^{\circ} \mathrm{C}$ until analysis. DNA was extracted from male specimens to assure the correct identification at the species level. Terminalia of these males were preserved in $70 \%$ ethanol and stored as vouchers at the Laboratory of Diptera at Museu Nacional, Universidade Federal do Rio de Janeiro, Rio de Janeiro.

Samples were transferred to a microtube and dried on a heating block at $65^{\circ} \mathrm{C}$ for $\sim 30$ min. DNA was extracted using $200 \mu \mathrm{L} \mathrm{DNAzol}{ }^{\circledR}$ (Invitrogen), following the manufacturer instructions, and purified with Microcon ${ }^{\circledR}$ (Millipore). DNA was amplified using primers and conditions described previously by Amorim et al. (2014).

Amplicons were purified using AxyPrep ${ }^{\mathrm{TM}}$ PCR Cleanup Kit (Axygen Biosciences $\left.^{\circledR}\right)$, following the manufacturer protocol. The sequencing reaction was performed with a BigDye ${ }^{\circledR}$ Terminator v3.1 Cycle Sequencing Kit (Applied Biosystems ${ }^{\circledR}$ ) and analyzed using a Genetic Analyzer AB3130 (Applied Biosystems ${ }^{\circledR}$ ), along with the program Sequencing Analysis Software v1.0. Sequence chromatograms were edited using Geneious ${ }^{\circledR}$ v4.7.5 (www.geneious.com) and deposited in GenBank. Several COI sequences from Sarcophaginae and Paramacronychiinae flesh flies and other fly families were obtained from GenBank to analyze the genetic distance. Consensus sequences were analyzed using the program MEGA 5 (Tamura et al., 2011) to obtain the multiple

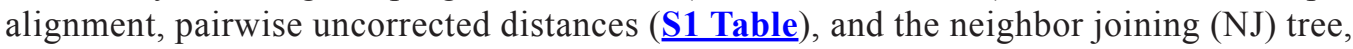
supported by 1000 bootstrap replicates.

\section{RESULTS AND DISCUSSION}

This study constitutes the first attempt to initiate a molecular reference database for Sarcophagidae species from the Rio de Janeiro area that are commonly found at crime scenes. This was especially the case for $O$. fluminensis, which is endemic to Brazil (Pape, 1996) and this study presents the first reported COI sequence for this species. Previous studies (Pape, 1996; Amorim et al., 2014) in São Paulo and the Bahia States have presented sequence data of the COI gene of $P$. intermutans only.

From 36 individuals, we obtained five different sequences comprising a single haplotype for O. fluminensis (JQ009192), two haplotypes for P. chrysostoma (JQ009193, JQ009194), and two haplotypes from P. intermutans (JQ009195, JQ009196). Interestingly, one of the P. intermutans haplotypes (JQ009195) is identical to one specimen (GQ409345) identified by Kutty et al. (2010), but not to one from São Paulo, Brazil (HM069340). The second P. intermutans haplotype (JQ009196) was identical to that from São Paulo, Brazil (HM069341). These findings confirm the reliability and demonstrate confidence in our 
obtained sequences.

Concerning intrageneric divergences (S1 Table and Table 1), the five Oxysarcodexia species analyzed have an average pairwise divergence of 0.081 , while the three Peckia species analyzed have an average divergence of 0.049. Divergences between genera of Sarcophagidae show an average pairwise divergence of 0.103 . Divergence values among Peckia and Oxysarcodexia were 0.120 and within P. chrysostoma this value was 0.003 and for $P$. intermutans was 0.007 ; these values correspond to those found for other forensically important fly species (Wallman and Donellan, 2001; Wells and Sperling, 2001; Zehner et al., 2004; Meiklejohn et al., 2011).

Table 1. Intra- and interspecific mean genetic divergences (uncorrected p-distances) of three species analyzed for the mitochondrial cytochrome c oxidase subunit I (COI), with the correspondent standard error of mean (means $\pm \mathrm{SEM}$ ). The minimum and maximum values are shown in parentheses.

\begin{tabular}{|c|c|c|c|c|c|c|c|}
\hline & Calliphoridae & Sarcophagidae & Oxysarcodexia & O. fluminensis & Peckia & P. chrysostoma & P. intermutans \\
\hline \multirow[t]{2}{*}{ Calliphoridae } & $* *$ & $0.123 \pm 0.0141$ & $0.134 \pm 0.013$ & $0.128 \pm 0.025$ & $0.113 \pm 0.008$ & $0.104 \pm 0.006$ & $0.118 \pm 0.003$ \\
\hline & & $(0.088-0.165)$ & $(0.110-0.153)$ & $(0.110-0.145)$ & $(0.098-0.123)$ & $(0.098-0.110)$ & $(0.113-0.123)$ \\
\hline \multirow[t]{2}{*}{ Sarcophagidae } & & $0.103 \pm 0.0241$ & $0.123 \pm 0.013$ & $0.118 \pm 0.014$ & $0.104 \pm 0.015$ & $0.104 \pm 0.016$ & $0.098 \pm 0.022$ \\
\hline & & $(0.000-0.180)$ & $(0.088-0.158)$ & $(0.075-0.155)$ & $(0.065-0.153)$ & $(0.030-0.140)$ & $(0.000-0.153)$ \\
\hline \multirow[t]{2}{*}{ Oxysarcodexia } & & & $0.081 \pm 0.044$ & $0.094 \pm 0.013$ & $0.120 \pm 0.011$ & $0.117 \pm 0.006$ & $0.121 \pm 0.013$ \\
\hline & & & $(0.000-0.130)$ & $(0.075-0.105)$ & $(0.098-0.153)$ & $(0.105-0.128)$ & $(0.108-0.153)$ \\
\hline \multirow[t]{2}{*}{ O.fluminensis } & & & & $* *$ & $0.113 \pm 0.006$ & $0.116 \pm 0.002$ & $0.113 \pm 0.004$ \\
\hline & & & & & $(0.098-0.118)$ & $(0.113-0.118)$ & $(0.108-0.118)$ \\
\hline \multirow[t]{2}{*}{ Peckia } & & & & & $0.049 \pm 0.04$ & $0.079 \pm 0.017$ & $0.048 \pm 0.040$ \\
\hline & & & & & $(0.000-0.093)$ & $(0.030-0.090)$ & $(0.000-0.093)$ \\
\hline \multirow[t]{2}{*}{ P. chrysostoma } & & & & & & $0.003 \pm 0.001$ & $0.085 \pm 0.003$ \\
\hline & & & & & & $(0.003-0.005)$ & $(0.080-0.090)$ \\
\hline \multirow[t]{2}{*}{ P. intermutans } & & & & & & & $0.007 \pm 0.005$ \\
\hline & & & & & & & $(0.000-0.015)$ \\
\hline
\end{tabular}

**Data not available.

In order to implement a molecular comparison, $\mathrm{NJ}$ analysis was performed with our sequences and those from members of Sarcophagidae and outgroups (Calliphoridae and Muscidae). As shown in Figure 1, specimens of $P$. intermutans formed a monophyletic group, separated from $P$. chrysostoma, although both species are closely related, and Oxysarcodexia was separate and distinct. Peckia, Oxysarcodexia, Boettcheria, and Ravinia formed a group separate from Sarcophaga and the outgroup, including Oxysarcodexia as a sister group of Ravinia, as found by Giroux et al. (2010), based on larval biology and adult morphology. The monophyletic separation of $P$. chrysostoma and $P$. intermutans in the phylogenetic tree, which is supported by strong bootstrapping values, confirms the sufficient resolution of the 400-bp COI fragment. This is the first report for $O$. fluminensis, which we could only compare among the genera.

In summary, sequences obtained from the mitochondrial COI gene fragment of $O$. fluminensis, $P$. chrysostoma, and P. intermutans are now available and can be used as an additional tool for the identification of populations from the City of Rio de Janeiro, especially in forensic applications, as previously described for West European Sarcophaga species (Jordaens et al., 2013). 
DNA identification of Sarcophagidae from Rio de Janeiro

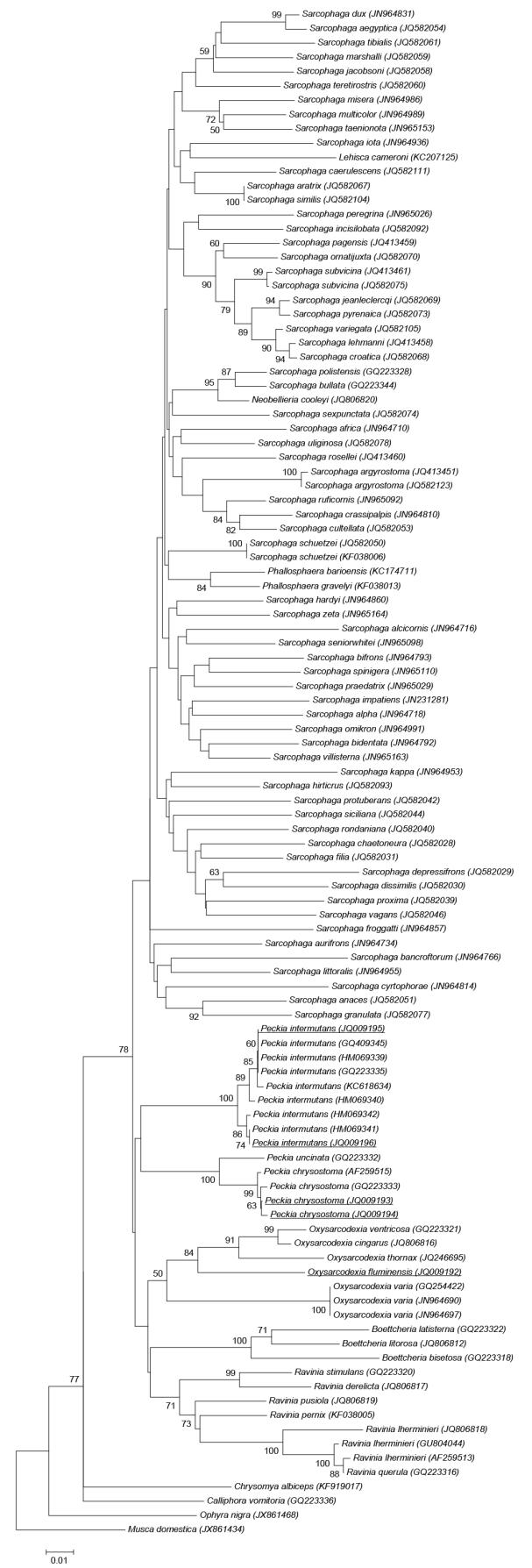

Figure 1. Neighbor joining (NJ) phylogram for 107 COI sequences of flesh flies and outgroup families. Values below branches correspond to NJ bootstrap and each sample with respective accession number in GenBank. The five sequences from Rio de Janeiro are underlined. 


\section{Conflicts of interest}

The authors declare no conflict of interest.

\section{ACKNOWLEDGMENTS}

We thank the outstanding technical support of Priscilla Menezes, from the Laboratory of Forensic Molecular Biology, Institute of Biology, UFRJ, and Cesar Schmidt, Laboratory of Macromolecular Metabolism Firmino Torres Castro, Institute of Biophysics Carlos Chagas Filho, UFRJ. Financial support was provided by FAPERJ, CNPq, and CAPES.

\section{REFERENCES}

Amorim JA, Souza CM and Thyssen PJ (2014). Molecular characterization of Peckia (Pattonella) intermutans (Walker, 1861) (Diptera: Sarcophagidae) based on the partial sequences of the mitochondrial cytochrome oxidase I gene. $J$. Forensics Res. 5: 3.

Barbosa RR, Mello-Patiu CA, Mello RP and Queiroz MMC (2009). New records of calyptrate dipterans (Fanniidae, Muscidae and Sarcophagidae) associated with the decomposition of domestic pigs in Brazil. Mem. Inst. Oswaldo Cruz 104: 923-926.http://dx.doi.org/10.1590/S0074-02762009000600018

Barbosa RR, Mello-Patiu CA, Ururahy-Rodrigues A, Barbosa CG, et al. (2010). Temporal distribution of ten calyptrate dipteran species of medicolegal importance in Rio de Janeiro, Brazil. Mem. Inst. Oswaldo Cruz 105: 191-198.http:// dx.doi.org/10.1590/S0074-02762010000200014

Byrd JH and Castner JL (2011). Insects of forensic importance. 2 ed. CRC, Boca Raton, FL, US.

Carvalho LML, Thyssen PJ, Linhares AX and Palhares FAB (2000). A checklist of arthropods associated with pig carrion and human corpses in southeastern brazil. Mem. Inst. Oswaldo Cruz 95: 135-138.http://dx.doi.org/10.1590/S0074$\underline{02762000000100023}$

Carvalho LML, Thyssen PJ, Goff ML and Linhares AX (2004). Observation on the succession patterns of necrophagous insect on a pig carcass in a urban area of southeastern Brazil. Internet J. Forensic Med. Toxicol 5: 33-39.

Carvalho CJB and Mello-Patiu CA (2008). Key to the adults of the most common forensic species of Diptera in South America. Rev. Bras. Entomol. 52: 390-406. http://dx.doi.org/10.1590/S0085-56262008000300012

Giroux M, Pape T and Wheeler TA (2010). Towards a phylogeny of the flesh flies (Diptera: Sarcophagidae): morphology and phylogenetic implications of the acrophallus in the subfamily Sarcophaginae. Zool. J. Linn. Soc. 158: 740-778. http://dx.doi.org/10.1111/j.1096-3642.2009.00561.x

Guo YD, Cai JF, Xiong F, Wang HJ, et al. (2012). The utility of mitochondrial DNA fragments for genetic identification of forensically important sarcophagid flies (Diptera: Sarcophagidae) in China. Trop. Biomed. 29: 51-60.Jordaens K, Sonet G, Richet R, Dupont E, et al. (2013). Identification of forensically important Sarcophaga species (Diptera: Sarcophagidae) using the mitochondrial COI gene. Int. J. Legal Med. 127: 491-504.http://dx.doi.org/10.1007/ s00414-012-0767-6

Kutty SN, Pape T, Wiegmann BM and Meier R (2010). Molecular phylogeny of the Calyptratae (Diptera: Cyclorrhapha) with an emphasis on the superfamily Oestroidea and the position of Mystacinobiidae and McAlpine's fly. Syst. Entomol. 35: 614-635. http://dx.doi.org/10.1111/j.1365-3113.2010.00536.x

Meiklejohn KA, Wallman JF and Dowton M (2011). DNA-based identification of forensically important Australian Sarcophagidae (Diptera). Int. J. Legal Med. 125: 27-32.http://dx.doi.org/10.1007/s00414-009-0395-y

Moura MO, de Carvalho CJ and Monteiro-Filho ELA (1997). A preliminary analysis of insects of medico-legal importance in Curitiba, State of Paraná. Mem. Inst. Oswaldo Cruz 92: 269-274.http://dx.doi.org/10.1590/S0074$\underline{02761997000200023}$

Oliveira TC and Vasconcelos SD (2010). Insects (Diptera) associated with cadavers at the Institute of Legal Medicine in Pernambuco, Brazil: implications for forensic entomology. Forensic Sci. Int. 198: 97-102.http://dx.doi.org/10.1016/j. forsciint.2010.01.011

Pape T (1996). Catalogue of Sarcophagidae of the world (Insecta, Diptera). Memoirs on Entomology. Florida: International, p558.

Saigusa K, Matsumasa M, Yashima Y, Takamiya M, et al. (2009). Practical applications of molecular biological species identification of forensically important flies. Leg Med (Tokyo) 11 (Suppl 1): S344-S347.http://dx.doi.org/10.1016/j. legalmed.2009.01.026 
Schroeder H, Klotzbach H, Elias S, Augustin C, et al. (2003). Use of PCR-RFLP for differentiation of calliphorid larvae (Diptera, Calliphoridae) on human corpses. Forensic Sci. Int. 132: 76-81.http://dx.doi.org/10.1016/S0379$\underline{0738(02) 00457-7}$

Smith KGV (1986). A manual of forensic entomology. Oxford University Printing House. p205.

Tamura K, Peterson D, Peterson N, Stecher G, et al. (2011). MEGA5: molecular evolutionary genetics analysis using maximum likelihood, evolutionary distance, and maximum parsimony methods. Mol. Biol. Evol. 28: 2731-2739. http://dx.doi.org/10.1093/molbev/msr121

Tan SH, Rizman-Idid M, Mohd-Aris E, Kurahashi H, et al. (2010). DNA-based characterisation and classification of forensically important flesh flies (Diptera: Sarcophagidae) in Malaysia. Forensic Sci. Int. 199: 43-49.http://dx.doi. org/10.1016/j.forsciint.2010.02.034

Wallman JF and Donnellan SC (2001). The utility of mitochondrial DNA sequences for the identification of forensically important blowflies (Diptera: Calliphoridae) in southeastern Australia. Forensic Sci. Int. 120: 60-67.http://dx.doi. org/10.1016/S0379-0738(01)00426-1

Wells JD, Pape T and Sperling FAH (2001). DNA-based identification and molecular systematics of forensically important Sarcophagidae (Diptera). J. Forensic Sci. 46: 1098-1102.http://dx.doi.org/10.1520/JFS15105J

Wells JD and Sperling FA (2001). DNA-based identification of forensically important Chrysomyinae (Diptera: Calliphoridae). Forensic Sci. Int. 120: 110-115.http://dx.doi.org/10.1016/S0379-0738(01)00414-5

Wells JD and Stevens JR (2008). Application of DNA-based methods in forensic entomology. Annu. Rev. Entomol. 53: 103-120.http://dx.doi.org/10.1146/annurev.ento.52.110405.091423

Zehner R, Amendt J, Schütt S, Sauer J, et al. (2004). Genetic identification of forensically important flesh flies (Diptera: Sarcophagidae). Int. J. Legal Med. 118: 245-247.http://dx.doi.org/10.1007/s00414-004-0445-4

\section{Supplementary material}

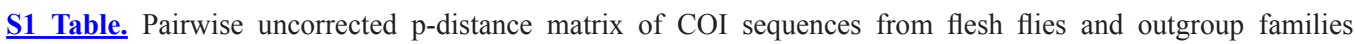
(GenBank Accession Number). 